\title{
Workshop Session Recordings on Green Volunteering Activities of Students in a Disadvantaged Area According to the Good-Hearted Vocation Teacher to Support Itinerant Junk Buyers
}

\author{
Kuntida Thamwipat \\ Faculty of Industrial Education and Technology \\ King Mongkut's University of Technology Thonburi \\ Bangkok, Thailand
}

\author{
Thanakarn Kumphai \\ Faculty of Industrial Education and Technology \\ King Mongkut's University of Technology Thonburi \\ Bangkok, Thailand
}

\begin{abstract}
This project was aimed to provide workshop session recordings on green volunteering activities of students in one disadvantaged area under the bridge of zone 1, Pracha-Utit Road 76, Toong-kru District, Bangkok where the majority worked as itinerant junk buyers. Therefore, the students held workshop sessions with the aim to provide training on how to repair electrical appliances and engines so that the community members could use this knowledge to increase the value of the unwanted electrical appliances they bought. The project also discussed the risk and danger of certain junk product which might be mixed with rubbish and taught how to classify recyclable products to increase the value of the junk. This project was the first of its own and it was done as green volunteering activities of students. The research team has provided 182 families from the community under the bridge of zone 1 with a number of workshop sessions. The sampling group was chosen out of those who attended at least three times and there were 20 persons. The research results showed that the sampling group achieved high level of knowledge $(\mathbf{1 0 0 . 0 \%})$. They could fix fans as well as repair and maintain engines. They could classify junk. They expressed high level of satisfaction towards the workshop sessions (mean score of 4.18 with S.D. of 0.27 ). When the assessment was conducted as regards the operation and the recordings on green volunteering activities of 13 students, it was at the highest level (mean score of 4.68 with S.D. of 0.42 ). This workshop project was the first runner-up of the national SCB Challenge 2012 Community Project as organized by Siam Commercial Bank PLC.
\end{abstract}

Keywords-Recordings; Workshop; Student Activities; Green Volunteering; Disadvantaged Community

\section{BACKGROUND}

The communities under the bridge in many parts of Bangkok are places where many homeless lived. Bangkok Metropolitan Administration and National Housing Agency have collaborated to provide over 700 families of these people with 3 plots of land which are not far from their previous places. These are the community under the bridge at PrachaUtit 76, Toong-kru District (Zone 1), the community under the bridge at Poonsarp, Saimai District (Zone 2) and the community under the bridge at Onnuch, Prawate District (Zone 3 ). The community under the bridge of zone 1 is located at Pracha-Utit Road Soi 76, Toong-kru District, Bangkok which is about 10 kilometres away from King Mongkut's University of Technology Thonburi. This 13 -rai* (*1 rai is equal to 1,600 square metres) plot of land houses 182 families at the moment. There are public areas such as sports field, playground, and pre-school development centre to hold meetings and activities among family members. The majority of people or over $70 \%$ of them work as itinerant junk buyers, in other words, they buy and collect unwanted or faulty electrical appliances, litter, empty plastic bottles, paper and the like and then they classify and sell them later. The majority of people are poor and their educational level was not high. They use saleng or threewheeled pedal cart as their vehicle and as such, their community is sometimes called "Saleng Community" which is one of many disadvantaged communities in Thailand.

In 2011, King Mongkut's University of Technology Thonburi (KMUTT) conducted the research study entitled "Community Research Project to Reduce and Solve the Social Inequality in Bangkok: A Case Study of Community under the Bridge of Zone 1, Toong-kru District, Bangkok" [1] with National Institute of Development Administration and Bangkok Metropolitan Administration in order to examine and analyse the current situations and requirements of the community. The results from this research included 15 developmental policy plans which had been amended by the community commission and the community people. The main aim is to develop the community continuously. The working group in this project consisted of 13 second-year and third-year undergraduate students from Faculty of Industrial Education and Technology, King Mongkut's University of Technology Thonburi under supervision by their advisors to depict the problems of the disadvantaged community. Therefore, the working group proposed to hold workshop sessions about green volunteering activities entitled "Good-Hearted Vocation Teacher to Support Itinerant Junk Buyers" to offer training sessions on repairing electrical appliances and engines so that the community members could apply this knowledge to their profession, namely buying unwanted or faulty products. They could fix faulty products to sell with more value and maintain their saleng or pedal cart to reduce the maintenance cost.

Besides, the workshop sessions were also aimed at developing the bodies of knowledge and the potentials of the 
working group. Since the students were studying electrical education and mechanical education to become vocation teachers in the future, they could develop their ability to teach their knowledge both in theory and in practice through these workshop sessions [2]. Apart from the knowledge about repairing electrical appliances and maintaining engines, the project also discussed the risk and danger of certain junk product and each type of rubbish [3] as well as how to give first aid. The working group hopes that the knowledge about repairing appliances and maintaining engines as well as understanding about safety and rubbish classification will meet the needs of the community so that their life conditions are of better quality.

\section{RESEARCH OBJECTIVES}

A. To hold workshop sessions about how to repair electrical appliances, how to maintain engines and how to classify rubbish for the people in the community under the bridge of zone 1 .

B. To measure the knowledge about how to repair electrical appliances, how to maintain engines and how to classify rubbish of the people in the community under the bridge of zone 1 .

C. To examine the satisfaction towards the workshop sessions about how to repair electrical appliances, how to maintain engines and how to classify rubbish as expressed by the people in the community under the bridge of zone 1.

D. To assess the results from the operation and the recordings about green volunteering activities of students who participated in the project.

\section{RESEARCH SCOPE}

The data in this research were collected in the second term of the academic year 2011 between January and February 2011 in WatPuttabucha Market and nearby communities only.

A. Skills in repairing electrical appliances: There were 3 parts in this training session:

1) Basic understanding about electrical appliances and repair kit.

2) How to repair household appliances, including rice cooker, kettle, iron and fan..

3) How to install electric wiring.

B. Skills in repairing and maintaining engines: There were 2 parts in this training session:

1) How to notice the faults and how to fix engines, including basic understanding about motorcycle electric system, water soaked engine, and engine basics.

2) How to replace motor devices such as replacing oil, mending punctures, and replacing tyres.

C. Understanding about various types of rubbish and how to classify them

1) Understanding about each type of rubbish.

2) Principles and technique in classifying rubbish.
3) Danger and risk from rubbish.

4) First aid for those in danger of rubbish.

To run the project and each workshop session, the working group of students and presenters would provide the community members with knowledge and training under the supervision of advisors as shown in Table 1.

TABLE I. SHOWS THE ROLES AND RESPONSIBILITIES IN EACH ACTIVITY

\begin{tabular}{|c|c|c|c|}
\hline Activity/Phase & $\begin{array}{c}\text { The working } \\
\text { group of } 13 \\
\text { students } \\
\end{array}$ & Advisory Board & $\begin{array}{l}\text { Benefits to the } \\
\text { Community }\end{array}$ \\
\hline $\begin{array}{l}\text { Preparation } \\
\text { and Data } \\
\text { Collection }\end{array}$ & $\begin{array}{l}\text { Data and } \\
\text { contents were } \\
\text { collected for } \\
\text { the project/ } \\
\text { workshop }\end{array}$ & $\begin{array}{l}\text { The appropriateness } \\
\text { of the contents were } \\
\text { considered }\end{array}$ & - \\
\hline $\begin{array}{l}\text { Campaigning } \\
\text { for the project } \\
\text { at the site }\end{array}$ & $\begin{array}{l}\text { Media were } \\
\text { created and } \\
\text { the campaign } \\
\text { was done at } \\
\text { the site }\end{array}$ & $\begin{array}{l}\text { Field trip with the } \\
\text { students to inform } \\
\text { the community } \\
\text { commission of the } \\
\text { details }\end{array}$ & $\begin{array}{l}\text { The community } \\
\text { members got } \\
\text { information and } \\
\text { prepared } \\
\text { themselves for } \\
\text { the workshop }\end{array}$ \\
\hline $\begin{array}{l}\text { Workshop } \\
\text { session 1: How } \\
\text { to repair } \\
\text { electrical } \\
\text { appliances }\end{array}$ & $\begin{array}{l}\text { Electrical } \\
\text { students ran } \\
\text { the workshop }\end{array}$ & $\begin{array}{l}\text { Field trip and } \\
\text { guidance to students }\end{array}$ & $\begin{array}{l}\text { The community } \\
\text { members gained } \\
\text { knowledge and } \\
\text { hands-on } \\
\text { experience with } \\
\text { electrical } \\
\text { appliances } \\
\end{array}$ \\
\hline $\begin{array}{l}\text { Workshop } \\
\text { session 2: How } \\
\text { to repair and } \\
\text { maintain } \\
\text { engines }\end{array}$ & $\begin{array}{l}\text { Mechanical } \\
\text { students ran } \\
\text { the workshop }\end{array}$ & $\begin{array}{l}\text { Field trip and } \\
\text { guidance to students }\end{array}$ & $\begin{array}{l}\text { The community } \\
\text { members gained } \\
\text { knowledge and } \\
\text { hands-on } \\
\text { experience with } \\
\text { engines }\end{array}$ \\
\hline $\begin{array}{l}\text { Workshop } \\
\text { session 3: } \\
\text { Types of } \\
\text { rubbish and } \\
\text { how to classify } \\
\text { them }\end{array}$ & $\begin{array}{l}\text { Guest } \\
\text { speakers to } \\
\text { run the } \\
\text { workshop } \\
\text { while } \\
\text { students } \\
\text { supported } \\
\text { them }\end{array}$ & $\begin{array}{l}\text { Field trip and } \\
\text { guidance to students }\end{array}$ & $\begin{array}{l}\text { The community } \\
\text { members } \\
\text { applied this } \\
\text { knowledge to } \\
\text { the safety issues } \\
\text { in their } \\
\text { profession }\end{array}$ \\
\hline $\begin{array}{l}\text { Follow-up and } \\
\text { Assessment }\end{array}$ & $\begin{array}{l}\text { Interviews } \\
\text { and data } \\
\text { collection } \\
\text { through } \\
\text { questionnaire } \\
\end{array}$ & $\begin{array}{l}\text { Field trip and } \\
\text { interviews with the } \\
\text { community } \\
\text { commission }\end{array}$ & - \\
\hline $\begin{array}{l}\text { Report on the } \\
\text { Operation }\end{array}$ & $\begin{array}{l}\text { Results from } \\
\text { the operation } \\
\text { were gathered } \\
\text { and written } \\
\text { up in the final } \\
\text { report }\end{array}$ & Report approval & - \\
\hline
\end{tabular}

\section{POPUlATION AND THE SAMPLING GROUP}

The population in this study were 182 families living in the community under the bridge of zone 1, Pracha-Utit 76 and working as itinerant junk buyers. The sampling group was chosen using purposive sampling method out of those who attended at least 3 workshop sessions. There were 20 persons in total. 


\section{TOOLS For Data COLleCtion}

A. The observation form to measure the level of understanding after the workshop

B. The questionnaire with Likert's 5-rating scale to measure the satisfaction towards the workshop

C. The self-assessment form for the working group

\section{Statistical Methods Used}

Percentage, Mean and Standard Deviation.

\section{RESEARCH RESULTS}

A. Workshop sessions on repairing electrical appliances, fixing engines and how to classify rubbish

1) Unwanted? Give us! $\leftarrow$ Preparation $\rightarrow$ Community (Field Trip, Survey of what's needed, Meetings, Review, Safety Training).

2) Public relations.

3) Teaching Preparation and Plan.

4) Training $\rightarrow$ Sessions 1-6: Repairing Electrical Appliances, Sessions 7-9: Repairing Engines, Session 10: Classifying Rubbish and Safety, Session 11: Painting the field.

5) Trainees need to repair electrical appliances within the time limit $\leftarrow$ Assessment with Electrical Appliances.

6) Summary $\rightarrow$ Number of attendants, Community technicians, Satisfaction.

7) Follow-up $\rightarrow$ Statistical data.

The project began the field trip and ran the operation from October 2012 to January 2013.

$B$. The results about the level of understanding for 3

workshop sessions

The level of understanding was assessed individually during the time set for the test in which the participant had to repair or fix the faulty parts in the device. The assessment was done in the following details: how to use devices, how to troubleshoot the problems, how to choose or replace the spare parts, and how to mend it according to the training session. The level of understanding could be discussed as follows:

\section{a) Repairing Electrical Appliances}

TABLE II. SHOWS THE NUMBER OF PEOPLE AND THE LEVEL OF UNDERSTANDING ABOUT HOW TO REPAIR ELECTRICAL APPLIANCES

\begin{tabular}{|l|c|c|c|c|}
\hline $\begin{array}{l}\text { Topic/ No. } \\
\text { of persons }\end{array}$ & Maintenance & $\begin{array}{c}\text { Dismantling and } \\
\text { basic } \\
\text { troubleshooting }\end{array}$ & $\begin{array}{c}\text { Analysis } \\
\text { and } \\
\text { repair }\end{array}$ & Note \\
\hline Fan & 3 & 4 & 20 & $100 \%$ \\
\hline Iron & 5 & 7 & 11 & \\
\hline Rice cooker & 5 & 7 & 11 & \\
\hline Kettle & 5 & 7 & 11 & \\
\hline TV & 1 & 15 & 5 & $\begin{array}{l}\text { To repair } \\
\text { TV needs } \\
\text { lot of } \\
\text { details } \\
\text { and more } \\
\text { time }\end{array}$ \\
\hline
\end{tabular}

b) Repairing and Maintaining Engines
TABLE III. SHOWS THE NUMBER OF PEOPLE AND THE LEVEL OF UNDERSTANDING ABOUT HOW TO REPAIR AND MAINTAIN ENGINES

\begin{tabular}{|l|c|c|l|}
\hline $\begin{array}{l}\text { Topic/ No. } \\
\text { of persons }\end{array}$ & $\begin{array}{c}\text { Maintenance } \\
\text { and basic } \\
\text { check-up }\end{array}$ & $\begin{array}{c}\text { Analysis } \\
\text { and } \\
\text { replacement }\end{array}$ & \multicolumn{1}{|c|}{ Note } \\
\hline $\begin{array}{l}\text { Replacing } \\
\text { oil, }\end{array}$ & 5 & 20 & $\begin{array}{l}100 \% \text { (Everybody } \\
\text { could do it because } \\
\text { they were familiar } \\
\text { with saleng) }\end{array}$ \\
$\begin{array}{l}\text { Cleaning } \\
\text { carburetor }\end{array}$ & & 20 & $\begin{array}{l}100 \% \text { (Everybody } \\
\text { could do it because } \\
\text { they were familiar } \\
\text { with saleng) }\end{array}$ \\
\hline $\begin{array}{l}\text { Mending } \\
\text { puncture, }\end{array}$ & 5 & & \\
$\begin{array}{l}\text { Fixing } \\
\text { chains }\end{array}$ & & & \\
\hline
\end{tabular}

c) Classifying Rubbish and Safety when Handling Rubbish and Junk

The trainees were familiar with the classification of rubbish. When they took a game test, they could win it. As for the topic of occupational health, it was still new to the community. After the training and the test on their understanding as well as the game activities and interviews, everybody, both adults and children, gained the highest level of understanding.

\section{Results about the Satisfaction towards the Green \\ Volunteering Activities Organized by Students}

The results about the satisfaction towards the green volunteering activities organized by students by the sampling group of 20 persons from different age groups and genders in the community were as follows:

TABLE IV. SHOWS THE SATISFACTION TOWARDS THE GREEN VOLUNTEERING ACTIVITIES ORGANIZED BY STUDENTS

\begin{tabular}{|c|c|c|c|}
\hline \multirow{2}{*}{ Item } & \multicolumn{3}{|c|}{ Satisfaction level } \\
\hline & Mean & S.D. & Meaning \\
\hline \multicolumn{4}{|l|}{ Speakers } \\
\hline 1. Clarity in knowledge transfer & 4.50 & 0.50 & High \\
\hline 2. Ability to explain the contents & 4.25 & 0.78 & High \\
\hline 3. Connection of contents and workshop & 4.35 & 0.74 & High \\
\hline 4. Comprehensiveness & 4.40 & 0.50 & High \\
\hline 5. Time efficiency & 4.05 & 0.82 & High \\
\hline 6. Questions and feedbacks to trainees & 4.35 & 0.67 & High \\
\hline Average & 4.32 & 0.62 & High \\
\hline \multicolumn{4}{|l|}{ Location/ Duration/ Catering } \\
\hline 1. Suitable location & 4.25 & 0.71 & High \\
\hline 2. Instructional facilities & 4.50 & 0.68 & High \\
\hline 3. Appropriate duration & 4.15 & 0.81 & High \\
\hline 4. Refreshments and prizes & 4.20 & 0.95 & High \\
\hline $\begin{array}{l}\text { Average } \\
\end{array}$ & 4.28 & 0.79 & High \\
\hline \multicolumn{4}{|l|}{ Application of Knowledge } \\
\hline $\begin{array}{l}\text { 1. Application of knowledge to } \\
\text { profession }\end{array}$ & 4.65 & 0.58 & High \\
\hline $\begin{array}{l}\text { 2. Confidence and adaptability of } \\
\text { knowledge }\end{array}$ & 4.40 & 0.59 & High \\
\hline 3. Ability to share knowledge & 4.30 & 0.92 & High \\
\hline $\begin{array}{c}\text { Average } \\
\end{array}$ & 4.45 & 0.69 & High \\
\hline Total Average & 4.18 & 0.27 & High \\
\hline
\end{tabular}


It could be concluded that the trainees' satisfaction towards the green volunteering activities of students according to the Good-Hearted Vocation Teacher to Support Itinerant Junk Buyers about the workshop sessions on repairing electrical appliances, fixing engines and classifying rubbish was at high level with mean score of 4.18 and S.D. of 0.27 .

D. Results about Self-Assessment of the Workshop Sessions by Students

TABLE V. SHOWS THE SATISFACTION TOWARDS THE GREEN VOLUNTEERING ACTIVITIES ORGANIZED BY STUDENTS

\begin{tabular}{|c|c|c|c|c|}
\hline Item & Mean & S.D. & Level & Rank \\
\hline Readiness for activities & 4.50 & 0.52 & High & 5 \\
\hline Step-by-step operation & 4.50 & 0.52 & High & 5 \\
\hline Task assignment & 4.75 & 0.45 & The Highest & 3 \\
\hline Collaboration and support & 4.83 & 0.38 & The Highest & 2 \\
\hline Endeavour & 5.00 & 0 & The Highest & 1 \\
\hline Information accuracy & 4.60 & 0.51 & The Highest & 4 \\
\hline Checking errors daily & 4.41 & 0.52 & High & 6 \\
\hline Mistake correction & 4.50 & 0.38 & High & 5 \\
\hline Accepting diverse opinions & 4.83 & 0.49 & The Highest & 2 \\
\hline Creativity in works & 4.60 & 0.49 & The Highest & 4 \\
\hline Success from activities & 4.83 & 0.38 & The Highest & 2 \\
\hline Average & 4.68 & 0.42 & The Highest & \\
\hline The results
\end{tabular}

The results about self-assessment of the green volunteering activities of 13 students were at the highest level with mean score of 4.68 and S.D. of 0.42 .

TABLE VI. RESUlTS ABOUT THE RECORDINGS AND THE PROBLEMS AS WELL AS SOLUTIONS DURING THE OPERATIONS

\begin{tabular}{|l|l|}
\hline \multicolumn{1}{|c|}{ Problems found } & \multicolumn{1}{c|}{ Solutions discussed } \\
\hline $\begin{array}{l}\text { 1. Trust from the } \\
\text { community members } \\
\text { because they thought } \\
\text { this project might } \\
\text { affect students' grade } \\
\text { or their graduation } \\
\text { status }\end{array}$ & $\begin{array}{l}\text { Details were given informally to the } \\
\text { community members through slideshows and } \\
\text { video clips about the SCB Community } \\
\text { Challenge Project. The chairperson was } \\
\text { elected to act as an intermediary between } \\
\text { students and community members. KMUTT } \\
\text { has a long experience with research and } \\
\text { community and door-knocking approach } \\
\text { could help both parties understand and gain } \\
\text { trust. }\end{array}$ \\
\hline $\begin{array}{l}\text { 2. The impact of training } \\
\text { on their profession }\end{array}$ & $\begin{array}{l}\text { The talk was organized between students and } \\
\text { community members to find the right time } \\
\text { for each training session and the contents } \\
\text { would be adjusted to fit the duration. }\end{array}$ \\
\hline $\begin{array}{l}\text { 3. Worries about basic } \\
\text { understanding before } \\
\text { the training }\end{array}$ & $\begin{array}{l}\text { The training sessions had to be easy and clear } \\
\text { with simple exercises before difficult } \\
\text { activities. Moreover, slideshows were shown } \\
\text { so that the trainees could see and practice the } \\
\text { real tools. The public relations were done } \\
\text { actively through door-knocking and colorful } \\
\text { advertisements. }\end{array}$ \\
\hline $\begin{array}{l}\text { Another team was specifically organized for } \\
\text { children with the topics about manners and } \\
\text { social etiquette, rules and beauty of the world } \\
\text { through video clips and games. This could } \\
\text { presentations }\end{array}$ & $\begin{array}{l}\text { help reduce the worries of many adults who } \\
\text { need to take care of their children. More } \\
\text { adults attended the training and the teachers } \\
\text { could manage their workshop easily without } \\
\text { children running around. }\end{array}$ \\
\hline $\begin{array}{l}\text { Oevices were prepared in advance before the } \\
\text { children came running } \\
\text { around, making } \\
\text { workshop sessions } \\
\text { hard to manage } \\
\text { prepared before each session through } \\
\text { practice with advisors and experienced } \\
\text { teachers in each area. Demonstrations were }\end{array}$ \\
\hline
\end{tabular}

\begin{tabular}{|l|l|}
\hline & $\begin{array}{l}\text { done before hands-on experiences in order to } \\
\text { time the whole process. Errors were } \\
\text { corrected and good understanding was built } \\
\text { among the working group in terms of } \\
\text { contents for each day and the age group. For } \\
\text { difficult areas, guest speakers would be } \\
\text { sought. }\end{array}$ \\
\hline $\begin{array}{l}\text { The sessions on engines needed saleng as the } \\
\text { main item for the whole training. The } \\
\text { location at outdoor public area was good but } \\
\text { the time of training was not suitable because } \\
\text { afternoon time was too hot although tents } \\
\text { were provided. There might be rain on some } \\
\text { days to test the endurance of the speakers and } \\
\text { the trainees. However, the working group } \\
\text { and the community offered refreshments to } \\
\text { cheer them up. }\end{array}$ \\
$\begin{array}{l}\text { Attendance was checked exactly at 1pm and } \\
\text { then theories were introduced before the } \\
\text { practical section. However, some community } \\
\text { members might be back from work later that } \\
\text { day but they would like to attend the } \\
\text { sessions. The teachers were afraid that they } \\
\text { might not catch up and as such a special team } \\
\text { was set for one-to-one tutorial to open up } \\
\text { opportunities for community members to } \\
\text { gain the same understanding. }\end{array}$ \\
\hline 7. Late attendance
\end{tabular}

\section{SugGestions}

\section{A. Short-term suggestions}

a) Another team should be set up to consolidate the knowledge of the community members by assigning some people to find faulty products so that they could practice repairing and gain knowledge. This could be helpful for everybody.

b) Additional skills should be provided to increase the expertise and to future advantages.

c) Brokers are needed to buy the goods from the community.

d) Housewives could be given a training session on inventions from unwanted products.

\section{B. Long-term suggestions}

a) Savings group should be established for disadvantaged groups in Bangkok.

b) Junk banks could be established to trade the products within the community.

\section{ACKNOWLEDGEMENTS}

Faculty of Industrial Education and Technology, King Mongkut's University of Technology Thonburi would like to express gratitude to the funding from Siam Commercial Bank PLC.

\section{REFERENCES}

[1] KingMongkut's University of Technology Thonburi, 2011, Community Research Project to Reduce and Solve the Social Inequality in Bangkok: A Case Study of Community under the Bridge of Zone 1, Toong-kru District, Bangkok, National Institute of Development Administration. pp. $20-32$.

[2] Faculty of Industrial Education and Technology , King Mongkut's University of Technology Thonburi , [Online], Available : http://www.fiet.kmutt.ac.th/home/index.php/about faculty,2013, [Retrieved 1 March, 2013]. 
[3] Energy Environment Safety and Health, King Mongkut's University of Technology Thonburi , [Online], Available http://www.eesh.kmutt.ac.th/doc/eesh_index_t.asp,2013,[Retrieved5 March ,2013].

[4] SCB Community Challenge 2009 [Online], Available : http://www.scbchallenge.com/challenge2009/community_howto.php , [Retrieved 4 March , 2013].

\section{APPENDIX}
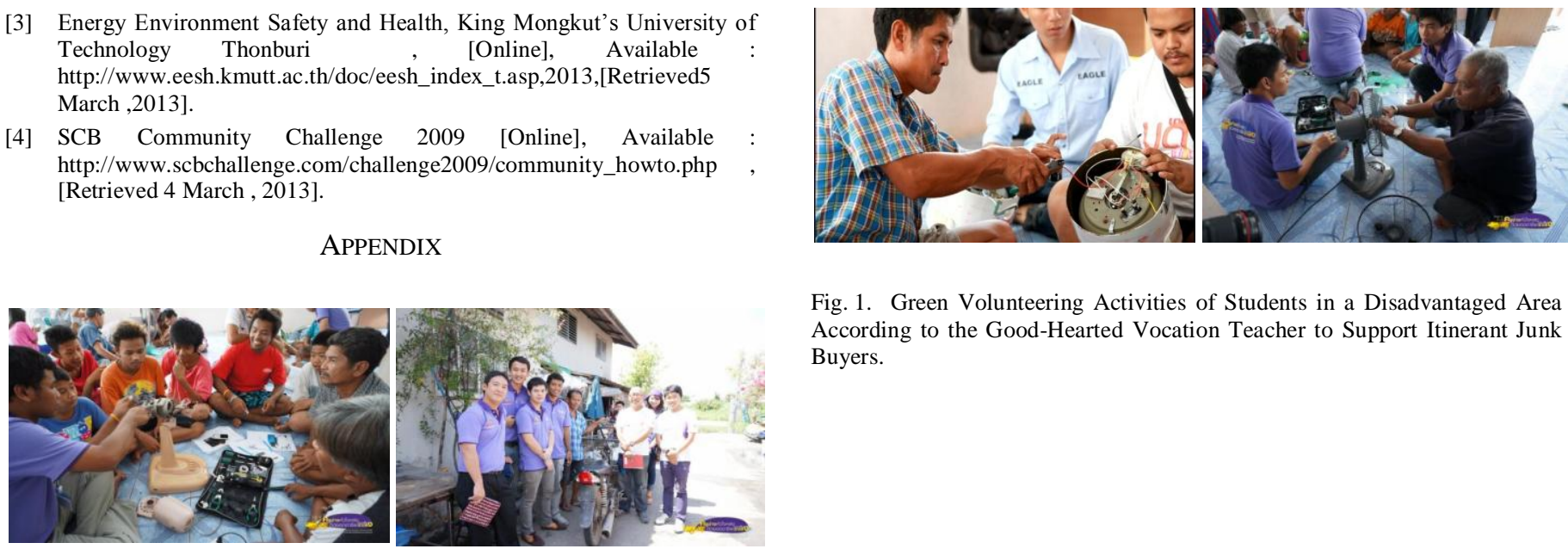

Fig. 1. Green Volunteering Activities of Students in a Disadvantaged Area According to the Good-Hearted Vocation Teacher to Support Itinerant Junk Buyers. 